\title{
Method for increasing the ecological and food value of meat of broiler and meat products
}

\author{
V.V. Tedtova ${ }^{1}$, Y.A. Yuldashbaev², A.S. Dzhaboeva ${ }^{3}$, V.R. Kairov ${ }^{4}$, D.A. \\ Yurin $^{5}$, Z.T. Baeva ${ }^{1}$, A.A. Baeva ${ }^{1}$, M.K. Kozhokov², A.V. Khmelevskaya ${ }^{6}$
}

${ }^{1}$ Chair of Technology of Food Products, North-Caucasian Mining and Metallurgical Institute (State Technological University), Vladikavkaz 362021, ${ }^{2}$ Chair of Private Animal Husbandry, Russian State Agrarian University - Moscow agricultural Academy after K.A. Timiryazev, Moscow 127550, ${ }^{3}$ Chair of Food Technology Products, KabardinoBalkarian State Agrarian University named after Kokov, Nalchik 360030, ${ }^{4}$ Chair of Commodity science and Examination of Goods. Gorsky State Agrarian University, Vladikavkaz 362040, ${ }^{4}$ North-Caucasian Research Institute of Mountain and Foothill Agriculture, Vladikavkaz Scientific Center of RAS, Vladikavkaz 362040, ${ }^{5}$ Department of Animal Feeding and Physiology, Krasnodar Research Centre for Animal Husbandry and Veterinary Medicine, Krasnodar 350055, ${ }^{6}$ Chairs of Anatomy, Physiology and Botany, North-Ossetian State University named after K.L. Khetagurov, Vladikavkaz, 362025, Russian Federation.

Corresponding author e-mail id: temiraev@ mail.ru

Journal of Livestock Science (ISSN online 2277-6214) 10:109-113

Received on 06/09/2019; Accepted on 01/11/2019

doi. 10.33259/JLivestSci.2019.109-113

\begin{abstract}
Currently there are many known enzyme preparations, which to varying level of efficiency split non-starchy polysaccharides in mixed feeds. The research aims to study the consumer qualities of broiler meat and its dishes when included enzyme preparations Celloviridin G20x and Amilosubtilin G3x into diets based on wheat grain (40\% by feed weight), barley (20\%) and soybean meal (15\%). The results obtained in the course of research were processed by mathematical analysis software package "Microsoft Excel". The best effect on the poultry slaughter qualities had joint supplements of multienzyme compositions Amilosubtilin G3x at a dose of $300 \mathrm{~g} / \mathrm{t}$ feed and Celloviridin G20x at a dose of $150 \mathrm{~g} / \mathrm{t}$ feed, which resulted in the superiority of chickens from the third test group over the control counterparts in weight of semi-eviscerated carcass by $14.5 \%$, eviscerated - by $15.1 \%$, slaughter yield $-0.66 \%$. Chickens, which were fed the mixture of preparations, surpassed their control counterparts in indicators characterizing the ratio of edible parts to inedible by $32.03 \%$. Use of enzyme preparations intensified protein metabolism in the poultry body, which contributed to improve the chemical composition and increase the biological value of meat protein. Due to this, in the femoral muscles the synthesis of dry matter and protein was more active, which in this muscle of broilers from the third test group resulted compared to the control in an increase of dry matter concentration by $2.674 \%$, protein - by $2.587 \%$. When studying the effect of heat treating chicken carcasses in the compared groups on the organoleptic characteristics, four samples of grilled chicken were cooked. The dish sample, the formulation of which included broiler carcasses of the third test group got top point total and surpassed the control counterparts in organoleptic qualities by 0.37 points. This superiority is provided, first of all, due to such parameters as flavor and tenderness.
\end{abstract}

Keywords: broilers; enzyme; slaughter indicators; consumer qualities of broiler meat; meat dish. 


\section{Introduction}

Development and introduction of intensive technologies to production dietary poultry meat is accompanied by a wider use of biologically active substances. However, direct, without a scientific approach, use of biologically active substances can cause a decrease in the physiological reserves of the chicken body that often lead to a decrease in the consumer qualities of their meat (Kokaeva, 2008; Kononenko et al., 2013). In the poultry body, biologically active additives, primarily enzyme preparations, activate all aspects of metabolism, thereby stimulating growth energy, increase in meat productivity and biological value of chicken meat (Gadzaonov et al., 2009; Temiraev et al., 2017).

Currently, there are many known enzyme preparations, which to varying level of efficiency split non-starchy polysaccharides of plant ingredients in mixed feeds, in this regard, a very important direction in the production of poultry meat is to study the determination of their impact on conversion of feed nutrients into meat products (Trukhachev et al., 2013; Tletseruk et al., 2013). The present research aims to study the consumer qualities of broilers meat and its dishes when included enzyme preparations Celloviridin G20x and Amilosubtilin G3x into diets based on wheat grain ( $40 \%$ by feed weight), barley (20\%) and soybean meal $(15 \%)$.

\section{Material and methods}

To achieve the aim the scientific-production experiment on broilers of cross «Smena-7» was conducted on the farm «Dur-Dur» in Digorsky district, RNO - Alania. 400 selected day old chickens were divided by analogue scale into 4 groups of 100 birds each, which were fed according to the scheme presented in Table 1. Meat productivity indicators were studied by standard practice. The composition and nutritional value of the experimental feed is shown in table 2.

Table 1 - Scheme of scientific and production experiment

\begin{tabular}{|l|l|}
\hline \multicolumn{1}{|c|}{ Group } & \multicolumn{1}{c|}{ Feeding habits } \\
\hline Control & Basic diet (BD) \\
\hline Test 1 & BD+ AmylosubtilinG3x at a dose of $300 \mathrm{~g} / \mathrm{t}$ mixed feed \\
\hline Test 2 & BD+CelloviridinG20x at a dose of $150 \mathrm{~g} / \mathrm{tmixed}$ feed \\
\hline Test 3 & $\begin{array}{l}\text { BD+AmylosubtilinG3x at a dose of } 300 \mathrm{~g} / \mathrm{t} \text { mixed feed+ } \\
\text { Celloviridin G20xat a dose of } 150 \mathrm{~g} / \mathrm{t} \text { mixed feed }\end{array}$ \\
\hline
\end{tabular}

Table 2 - Composition and nutritional value of feed for broiler chickens

\begin{tabular}{|l|c|}
\hline \multicolumn{1}{|c|}{ Ingredients } & Contained, $\%$ \\
\hline Wheat & 40.0 \\
\hline Barley & 20.0 \\
\hline Soybean meal & 15.0 \\
\hline Sunflower meal & 9.3 \\
\hline Dry bard & 5.6 \\
\hline Fish flour & 5.0 \\
\hline Common salt & 0.2 \\
\hline Defluorinated phosphate & 3.0 \\
\hline Feed fat & 0.9 \\
\hline Premix P6-1-89 & 1.0 \\
\hline \multicolumn{1}{|c|}{$100 \mathrm{~g}$ of feed contained: } \\
\hline exchange energy, mJ & 1339 \\
\hline crude protein & 21.0 \\
\hline raw fat & 6.49 \\
\hline crude fiber & 4.0 \\
\hline calcium & 1.2 \\
\hline phosphorus & 0.70 \\
\hline sodium & 0.20 \\
\hline lysine & 0.84 \\
\hline methionine + cystine & 0.84 \\
\hline Methionine was added to 1 ton of feed, g & 6.00 \\
\hline
\end{tabular}


To determine the fermentation intensity of nutrients in diets of 5 selected birds from each group, the activity of proteinases, cellulases, lipases and amylases in accordance with the standard practice was studied in the content of the gizzard stomach and duodenum after the control slaughter (Okolelova, 2001). The results obtained in the course of research were processed by mathematical analysis software package "Microsoft Excel".

\section{Results and Discussion}

It is known that the efficiency of broiler growing, along with the growth intensity, is largely due to their meat consumer qualities. Based on this, at 42 days of age the control slaughter of the experimental bird was carried out, for which 5 birds were selected from each group. The effect of enzyme preparations on slaughter indicators of chickens in the compared groups was studied by the results of the control slaughter (Table 3).

Table 3 - Slaughter indicators of experimental birds

\begin{tabular}{|l|c|c|c|c|}
\hline \multirow{2}{*}{\multicolumn{1}{|c|}{ Indicator }} & \multicolumn{3}{c|}{ Group } \\
\cline { 2 - 5 } & Control & Test 1 & Test 2 & Test 3 \\
\hline Pre-slaughter weight, g & 2044.30 & 2176.80 & 2220.72 & 2329.46 \\
\hline Weight of semi-eviscerated carcass, g & 1623.38 & 1722.15 & 1757.48 & 1859.14 \\
\hline Weight of eviscerated carcass, g & 1363.51 & 1457.83 & 1489.90 & 1569.18 \\
\hline Slaughter yield, \% & 66.70 & 66.97 & 67.09 & 67.36 \\
\hline Weight of edible parts, g & 1146.64 & 1258.48 & 1338.34 & 1462.89 \\
\hline Weight of inedible parts, g & 897.66 & 918.32 & 882.38 & 866.57 \\
\hline Ratio of edible to inedible parts & 1.28 & 1.37 & 1.52 & 1.69 \\
\hline
\end{tabular}

It is found that the best effect on the poultry slaughter qualities had joint supplements of multienzyme compositions Amilosubtilin G3x at a dose of $300 \mathrm{~g} / \mathrm{t}$ feed and Celloviridin G20x at a dose of $150 \mathrm{~g} / \mathrm{t}$ feed, which resulted in the superiority of chickens from the third test group over the control counterparts in weight of semi-eviscerated carcass by $14.5 \%$, eviscerated - by $15.1 \%$ as well as slaughter yield $-0.66 \%$.

During the experiment with increasing pre-slaughter weight and weight of the semi-eviscerated carcass there was an increase in the weight of edible parts relative to the weight of inedible parts. So chickens of the third test group which were fed the mixture of multienzyme compositions Amilosubtilin G3x and Celloviridin G20x exceeded their control counterparts in indicators characterizing the ratio of edible to inedible parts by $32.03 \%$.

Consumer qualities of meat depend not only on the content of muscle, connective and adipose tissue, but also on the chemical composition. Based on this, it was important to determine the chemical composition of the pectoral and femoris in the experimental bird and to calculate the protein quality index (PQI) of broilers meat from the compared groups (Table 4).

Table 4 - Chemical composition of femoris and pectoral and protein quality index (PQI) of the experimental poultry meat

\begin{tabular}{|l|c|c|c|c|}
\hline \multirow{2}{*}{ Indicator } & \multicolumn{4}{c|}{ Group } \\
\cline { 2 - 5 } & Control & Test 1 & Test 2 & Test 3 \\
\hline \multicolumn{5}{|c|}{ Femoris } \\
\hline Dry matter, \% & 21.018 & 23.116 & 23.250 & 23.692 \\
\hline Protein, \% & 18.377 & 19.297 & 20.307 & 20.964 \\
\hline Fat, \% & 3.189 & 2.987 & 2.845 & 2.689 \\
\hline \multicolumn{5}{|c|}{ Pectoral } \\
\hline Dry matter, \% & 23.494 & 24.360 & 24.534 & 25.254 \\
\hline Protein, \% & 20.215 & 21.957 & 21.659 & 22.989 \\
\hline Fat, \% & 2.929 & 2.831 & 2.359 & 2.235 \\
\hline & Protein quality index (PQI) & & 1.67 \\
\hline Tryptophan\% & 1.53 & 1.66 & 1.67 & 1.72 \\
\hline Oxyproline\% & 0.33 & 0.34 & 0.33 & 0.31 \\
\hline PQI & 4.64 & 4.88 & 5.06 & 5.55 \\
\hline
\end{tabular}


It was found that the use of enzyme preparations intensified protein metabolism in the poultry body, which contributed to improve the chemical composition and increase biological value of meat protein estimated by the content of the essential amino acid tryptophan and oxyproline in the pectoral. Due to this, in the femoral muscles the synthesis of dry matter and protein was more active, which in this muscle of broilers from the third test group resulted compared to the control in an increase of dry matter concentration by $2.674 \%$, protein - by $2.587 \%$.

The combined use of multienzyme compositions Amilosubtilin G3x and Celloviridin G20x had a synergistic effect on the poultry metabolism in the test groups, which allowed increase in the pectorals of chickens of the third test group versus the control dry matter and protein content, respectively, by 1.760 and $2.774 \%$. At the same time, during the experiment, the poultry of the third test group relative to the control counterparts showed a decrease of the fat concentration in the pectoral, which indicates an improvement in the energy value of their meat.

In the pectorals biochemical processes occur more intensively than in the femoris. At this, the pectorals contain somewhat more proteins, less fat and cholesterol. The results obtained showed that the joint feeding of multienzyme compositions Amilosubtilin G3x and Celloviridin G20x provided for chickens of the third test group compared to the control the superiority over the biological full value of meat by $19.6 \%$.

It is known that the consumer qualities of meat dishes are significantly affected by its chemical composition and biological value of protein. Protein molecule when heating undergoes complex physico-chemical changes, primarily denaturation and coagulation, the depth of which depends on temperature, length of heat processing and some other factors. After heat treatment it is easier to assess consumer qualities of broiler meat. Based on the foregoing, when studying the effect of heat treating chicken carcasses in the compared groups on the organoleptic characteristics, four samples of grilled chicken were cooked. To make the organoleptic evaluation of the compared samples of "grilled chicken" dish the seven-member taste panel of the Department of public catering production technology tasted samples of the ready dish (Table 5).

Table 5 - Organoleptic evaluation of "Grilled chicken" dish samples, points.

\begin{tabular}{|l|c|c|c|c|}
\hline \multirow{2}{*}{ Indicator } & \multicolumn{4}{c|}{ Group } \\
\cline { 2 - 5 } & Control & Test 1 & Test 2 & Test 3 \\
\hline Taste & 8.67 & 8.72 & 8.75 & 8.77 \\
\hline Flavour & 8.85 & 8.87 & 8.90 & 8.93 \\
\hline Juiciness & 8.60 & 8.62 & 8.64 & 8.67 \\
\hline Tenderness & 8.65 & 8.69 & 8.74 & 8.77 \\
\hline Overall score & 34.77 & 34.90 & 35.03 & 35.14 \\
\hline
\end{tabular}

It is found that in the course of the scientific and economic experiment, the chemical composition and biological value of protein in the pectoral largely influenced the overall score of the dish samples. According to the tasting results, the dish sample, the formulation of which included broiler carcasses of the third test group got top point total and surpassed the control counterparts in organoleptic qualities by 0.37 points. Moreover, this superiority is provided, first of all, due to such parameters as flavor and tenderness. It is evidence that when joint supplementation with enzyme preparations Amilosubtilin G3x and Celloviridin G20x the best consumer properties had the "Grilled chicken" dish sample the formulation of which included carcasses of broilers cross from the third test group.

\section{Conclusion}

To improve the consumer qualities of broilers meat and dish "Grilled chicken" multienzyme compositions Amilosubtilin G3x at a dose of $300 \mathrm{~g} / \mathrm{t}$ feed and Celloviridin G20x at a dose of $150 \mathrm{~g} / \mathrm{t}$ feed should be included in their diets based on wheat ( $40 \%$ of feed weight), barley (20\%) and soybean meal (15\%).

\section{References}

1). Kokaeva, M.G. 2008. Proceedings of the XII All-Russian scientific and practical conference "Agro-industrial complex and current problems of regional economy". - Maykop, Pp. 200-201.

2). Kononenko, S.I., Stolbovskaya A.A., Vityuk L.A., Payuchek V.G., Pilov A.Kh., Getokov O.O. 2013. Features of the digestive metabolism of broilers when violating the ecology of feeding Kononenko, // Polythematic network online scientific journal of Kuban State Agrarian University - Polythematic online scientific journal of Kuban State Agrarian University. 87(03): 408-417. 
3). Gadzaonov, R.Kh., Stolbovskaya A.A., Baeva A.A., Kibizov G.K. 2009. Use of antioxidant and mold inhibitor in broilers feed // Poultry breeding. 4: 23-24.

4). Temiraev R.B., Kozhokov, M.K., Cherchesova, S.K., Kokaeva, F.F. and Tletseruk, I.R. 2017. Method for diminishing the adverse effect of anthropogenic heavy metal pollution on poultry meat products. Journal of Environmental Management and Tourism. 813 (19): 567-573.

5). Trukhachev, V.I., Temiraev K.B., Tukkaev O.V., Zavkhalova S.Ch., Abaev A.V. 2013. A way to increase productivity and biological value of broiler meat, considering the food ecology // Procedings of international scientific and practical conference "Topical issues of improving technology for production and processing of agricultural products". - Stavropol. Pp. 143-148.

6). Tletseruk, I.R., Temiraev K.B., Tukkaev O.V., Abaev A.V. 2013. A way to improve ecological and nutritional qualities of poultry meat //New technologies. - Maykop. 3: 128-134.

7). Okolelova, T. 2001. Rye plus enzymes in broiler diets // Poultry breeding. 3: 36-38. 